\title{
Edukacja wczesnodziecięca w Japonii - przemiany programowe i organizacyjne
}

Japonia jest jednym z krajów, w którym edukacja i opieka nad dzieckiem we wczesnym okresie jego rozwoju wzbudza obecnie ogromne zainteresowanie różnych aktorów społecznych. Japońscy rodzice, a zwłaszcza matki podejmują liczne wysiłki w celu zapewnienia jak najlepszych warunków rozwojowych swoim dzieciom. W rodzinach powszechna jest świadomość golemanowskiego stwierdzenia, iż początkowy etap życia to swoiste okno możliwości (window of opportunity $)^{1}$.

Ponadto, wczesna opieka i edukacja wzbudza też zainteresowanie badaczy, teoretyków pedagogiki, psychologii i socjologii oraz praktyków podejmujących działalność profesjonalną w placówkach opiekuńczo-wychowawczych. I wreszcie - niezaburzony wczesny rozwój dzieci leży też w interesie dużych i małych grup społecznych oraz organizacji, które mogą istnieć dzięki ciągłości pokoleniowej.

Obecny kształt edukacji i opieki wczesnodziecięcej rozwijał się w Japonii w ciągu ostatnich 150 lat. Interesującym wydaje się podjęcie zadania dokonania opisu i analizy przemian programowych i organizacyjnych, jakie zachodziły właśnie w tej sferze. Rozwijając studium porównawcze japońskiej edukacji wczesnodziecięcej nie można pominąć tła kulturowego, społecznego, gospodarczego oraz politycznego, w ramach (i pod wpływem) którego zachodziły opisywane zmiany.

\section{Geneza edukacji wczesnodziecięcej w Japonii}

W toku historycznego rozwoju w różnych krajach kształtowano zróżnicowane sposoby myślenia o dziecku, a tym samym o sprawowaniu nad nim opieki oraz jego edukacji. Bezsprzecznie stosunek do małego dziecka warunkowany

\footnotetext{
${ }^{1}$ Por. D. Goleman, Emotional Intelligence: why it can matter than IQ, Bantam Books 1996.
} 
jest społecznie i kulturowo. Publikacje na ten temat w odniesieniu do rzeczywistości społecznej Japonii pojawiały się częściej wraz z otwarciem się i modernizacją tego kraju w epoce Meiji (1868-1912). Na przełomie XIX i XX wieku w Europie i Stanach Zjednoczonych publikowanych było wiele książek autorstwa podróżników i badaczy japońskiego życia ${ }^{2}$. Autorzy tych prac opisywali między innymi szczególny stosunek Japończyków do małych dzieci. Przez wiele stuleci utożsamiano je bowiem z darem bogów i uważano, że do siódmego roku życia pozostają one pod boską opieką. Żyły radośnie, beztrosko, doznając rozpieszczania przez członków wielopokoleniowych rodzin i troskliwej opieki ze strony społeczności lokalnej. Dorośli zobowiązani byli do ochrony wrodzonej, dobrej, dziecięcej natury przed złymi wpływami otoczenia. Szczególną rolę w sprawowaniu opieki odgrywały matki, które osobiście odpowiadały za takie wychowanie dziecka, aby było dobrym, uczciwym, przyzwoitym człowiekiem dorosłym. Matki w rodzinach o wysokim statusie zobowiązane były ponadto do przygotowania pierworodnego syna do podjęcia obowiązków doskonałego dziedzica. Współcześnie wiemy, że opisy tego „dziecięcego raju” pomijały tragedie dzieci żyjących $\mathrm{w}$ biedzie oraz negatywny wpływ patriarchalnego systemu rodzinnego ${ }^{3}$.

Początkowo edukacja i opieka nad małym dzieckiem w Japonii nie miała charakteru instytucjonalnego. Do drugiej połowy XIX wieku nie istniał w tym kraju powszechny, dostępny dla większości obywateli system szkolny. W 1871 roku w ramach Restauracji Meiji ${ }^{4}$ powołane zostało Ministerstwo Edukacji, na czele którego stanął najpierw Shimpei Eto, a po jego odejściu Arinori Mori, odpowiedzialny bezpośrednio za zreformowanie istniejących wcześniej w Japonii szkół. Podstawą prawną modernizacji był wydany przez cesarza w 1872 roku Government Order of Education (Gakusei). Nowy japoński system szkolny składał się zatem z 6 okręgów akademickich (w każdym z nich miał powstać uniwersytet), w których dokonano podziału na 32 rejony szkolnictwa średniego, tworzonego z kolei przez 210 szkół podstawowych. W pierwszych latach modernizacji do nowo powstałych szkół uczęszczało 40\% chłopców i 15\% dziewcząt w wieku szkolnym. Gakusei wprowadziła również trzyletni (wydłużony następnie do czterech lat) obowiązek szkolny obejmujący wszystkie dzieci, bez względu na pochodzenie społeczne, status ekonomiczny lub płeć. Po ukończeniu szkoły podstawowej drogi edukacyjne młodzieży uzależnione były

\footnotetext{
${ }^{2}$ Przykładem takiej książki był np. cykl wykładów na temat edukacji japońskiej wygłoszonych na Uniwersytecie Londyńskim i opublikowanych w 1909 roku przez Barona Dairoku Kikuchi (Japanese Education: Lectures Delivered in the University of London).

${ }^{3}$ M. Hosbi-Watanabe, Infant and Toddler Care in Japan, [w:] New R. S., Cochran M. (red), Early Childhood Education. An International Encyclopedia, t. 4, Praeger, Westport-London 2007, s. 1155.

${ }^{4}$ Czyli odnowienia, modernizacji państwa japońskiego po okresie zamknięcia, izolacji w epoce Edo (1603-1868).
} 
od przynależności społecznej. Kontynuowanie kształcenia odbywało się w pięciu różnych typach szkół średnich, a następnie w szkołach wyższych ${ }^{5}$.

Wyłonienie się powszechnego, trójszczeblowego systemu szkolnego było jedną okolicznością tworzącą warunki dla powstania instytucji wczesnej edukacji dzieci. Drugą stanowiła natomiast aktywizacja edukacyjna i zawodowa kobiet. Jednym z jej prekursorów był Masanao Nakamura (1832-1891) - znany pedagog, wykształcony w Anglii. W 1873 roku otworzył Nakamura prywatna wyższą szkołę dla kobiet, Dojinsha ${ }^{6}$. Do obowiązkowych programowo dzieł studiowanych przez uczące się w niej Japonki należały między innymi dwie prace Johna Stuarta Milla - On Representative Government oraz The Subjection of Women. Analiza tych tekstów miała rozwijać u studiujących nowe myślenie o roli i misji kobiet $w$ społeczeństwie japońskim. Swoje edukacyjne cele zrealizował Makamura całkowicie pełniąc w latach 1875-1880 - z ramienia rządu japońskiego - obowiązki dyrektora państwowego Tokijskiego Kolegium Nauczycielskiego dla Kobiet, Tōkyō Joshi Shihan Gakkō' . W 1876 roku zorganizował i otworzył przy uczelni dla kobiet pierwsze w Japonii przedszkole. W placówce tej realizowano koncepcję Friedricha Froebla. Dyrektorką przedszkola została Clara Matsuno, absolwentka szkoły pedagogicznej Froebla w Niemczech. Następnie wzorem tej placówki zaczęły powstawać kolejne przedszkola w różnych częściach Japonii. Początkowo stosowana w nich metoda darów Froebla w pełni odzwierciedlała pierwotny niemiecki wzorzec. Z czasem jednak związki z froeblowską filozofią rozluźniły się, a sposób pracy z dzieckiem stał się bardziej sformalizowany ${ }^{8}$.

Pod koniec XIX wieku powstały w Japonii dwie zasadnicze formy organizacyjne edukacji przedszkolnej - przedszkola (yōchien) oraz ośrodki opieki dziennej (hoikuen). Pierwsze skupiały dzieci klasy wyższej i średniej, drugie natomiast były tworzone dla dzieci rolników i robotników. Ponadto, do hoikuen często trafiały dzieci przed ukończeniem trzeciego roku życia. Jednak odsetek uczestników tych form opieki i edukacji był początkowo znikomy. Wynikało to głównie ze społecznie skonstruowanych wymogów sprawowania przez matki opieki we wczesnym okresie rozwoju dziecka ${ }^{9}$.

\footnotetext{
${ }^{5}$ M. Cylkowska-Nowak, Spoteczne funkcje szkolnictwa w Japonii i Stanach Zjednoczonych. Studium z pedagogiki porównawczej, Poznań-Toruń 2000, s. 67.

${ }^{6} \mathrm{Na}$ uwagę zasługuje fakt, iż była to jedna z trzech powstałych w epoce Meiji prywatnych szkół wyższych. Wszystkie pozostałe były szkołami cesarskimi o statusie państwowym.

${ }^{7}$ A. Ohta, Nakamura Masanao (Keiu), 1832-91: Translator into Japanese of Samuel Smiles 'Self Help', [w:] Cortazzi H., Nish J. H., Hoare J. E. (red.), Britain \& Japan: Biographical Portraits, Japan Society, Routledge, London 2003, s. 221-222.

${ }^{8}$ N. Kamigaichi, Pedagogy in Japan, [w:] New R. S., Cochran M. (red), Early Childhood Education. An International Encyclopedia, t. 4, Praeger, Westport-London 2007, s. 1168.

${ }^{9}$ E. Lassergard, Japan, [w:] International Handbook of Child Day Care Policies and Programs, Cochran M. (red.), Greenwood Press, Ne w York 1993, s. 322 I s. 324.
} 
W 1878 roku w Tokijskim Kolegium Nauczycielskim dla Kobiet zapoczątkowano kursy dla nauczycielek przedszkoli. Twórcą programów był profesor Sozo Kurahashi (1882-1955) ${ }^{10}$.

\section{Od pierwszych adaptacji programowych do edukacji ,zorientowanej na dziecko"}

Pierwsze wytyczne dotyczące edukacji przedszkolnej (Ustawa o wytycznych dotyczacych treści i pomocy $w$ edukacji przedszkolnej) wprowadzone zostały w 1899 roku przez japońskie Ministerstwo Edukacji (Monbushō). Wskazania te koncentrowały się na czterech dziedzinach treści edukacyjnych: zabawie, piosence, wymowie oraz pracach ręcznych. Ponadto, Ministerstwo ustanowiło własny nadzór i kontrolę nad przedszkolami, ogłosiło pierwsze narodowe standardy opieki oraz ustanowiło limity wieku (3 rok życia, jako wiek początkowy) i organizacyjne w przeliczeniu na 100 dzieci jako maksymalną liczebność, którą może osiągnąć każde z istniejących wówczas dwustu przedszkoli ${ }^{11}$.

Na początku XX stulecia dwóch pedagogów - Goroku Nakamura (kierownik przedszkola) i Minoru Wada (wykładowca Tokijskiego Kolegium Nauczycielskiego dla Kobiet) - zaproponowało zreformowanie obowiązujących programów nauczania. Zaproponowali oni zmianę programów z ukierunkowanych na nauczyciela na programy ukierunkowane na dziecko lub skoncentrowane na zabawie. Propozycja ta okazała się jednak zbyt nowatorska i postępowa, by mogła być w tym momencie szeroko zaakceptowana. W 1908 roku Nakamura i Wada wprowadzili do teorii i praktyki wczesnej edukacji obecne do dziś pojęcie yudo hoiku - co w wolnym tłumaczeniu oznacza kierowanq edukacje wczesnodziecięcq ${ }^{12}$.

Jednocześnie ciagłej krytyce poddawano metodę Froebla. Uważano ją za zbyt sztywną, formalną oraz zawierającą dużą ingerencję nauczyciela. Zamiast niej zaproponowano metody skoncentrowane na dziecku. Motokichi Higashi (1872-1958), ekspert pracujący w przedszkolu Tokijskiego Kolegium Nauczycielskiego dla Kobiet sugerował położenie większego nacisku na znaczenie swobodnej zabawy. Współpracując z przedszkolem, opracował programy edukacji skoncentrowanej na zabawie, a w 1904 roku opublikował książkę

${ }^{10}$ M. Hosbi-Watanabe, Infant and Toddler Care in Japan..., s. 1156.

${ }^{11}$ D. W. Shwalb, D. J. Shwalb, S. S. S. Tatsumoto, Japanese Nonmaternal Child Care: Past, Present, and Future, [w:] Lamb M. E., Sternberg K. J., Hwang C.-Ph., Broberg A. G. (red.), Child Care in Context: Cross-Cultural Perspectives, Erlbaum, Hillsdale (New Jersey) 1992.

${ }^{12}$ Y. Shirakawa, S. Kitano, Research and Policy Issues in Early Childhood Care and Education in Japan, [w:] Spodek B., Saracho O. N. (red.), International Perspectives on Research in Early Childhood Education, IAP, Greenwich (Connecticut) 2005, s. 139. 
pt. Metoda edukacji przedszkolnej. Była to pierwsza praca systematyzująca metodykę edukacji wczesnodziecięcej w Japonii ${ }^{13}$.

Kolejna faza przemian programowych edukacji wczesnodziecięcej związana była $\mathrm{z}$ wpływem na teorię i praktykę pedagogiczną w Japonii amerykańskiego progresywizmu. Najbardziej znaczące okazały się dwie znane koncepcje - Johna Deweya oraz Williama Kilpatricka. Japońscy teoretycy i praktycy opieki i edukacji małych dzieci zaczęli wówczas zmieniać myślenie o sposobie pracy z małym dzieckiem. W centrum teoretyzowania (oraz praktyk edukacyjnych) sytuowano rozwój indywidualności, kreatywności i spontaniczności. Twórcą teorii, w której odnaleźć można wpływy amerykańskiego progresywizmu, a jednocześnie uwzględnienie japońskich realiów, był wspomniany już wcześniej Sozo Kurahashi.

Wykładając psychologię rozwojową w Tokijskim Kolegium Nauczycielskim dla Kobiet, Kurahashi spędzał wiele czasu w działającym przy uczelni przedszkolu. Jego ulubionym zajęciem było obserwowanie i dyskutowanie wraz z nauczycielami i studentami spontanicznych, swobodnych zabaw dzieci. Od 1917 roku sprawował obowiązki dyrektora tej placówki przedszkolnej. Z jego polecenia wszystkie zabawki znajdujące się w placówce umieszczono w wielkich koszach po to, aby dzieci mogły samodzielnie i niezależnie dokonywać wyboru przedmiotów do własnych zabaw. Należy w tym miejscu dodać, że była to wówczas odosobniona praktyka w japońskich przedszkolach. Prowadzone obserwacje łączył Kurahashi ze studiowaniem prac Jana Amosa Komeńskiego, Jana Jakuba Rousseau i Johanna Heinricha Pestalozziego oraz doświadczeniem teorii i praktyki Marii Montessori i Friedricha Froebla podczas podróży po Europie i Stanach Zjednoczonych ${ }^{14}$.

W wyniku przeprowadzonych studiów Sozo Kurahashi opracował interesująca, zwartą koncepcję edukacji wczesnodziecięcej. Dokonał on połączenia sposobu myślenia pedagogów zachodnich z własną praktyką przedszkolną i tradycyjnymi japońskimi poglądami na rozwój i opiekę nad dziećmi. Teoria ta została opublikowana przez Kurahashi w kolejnych książkach: Edukacja przedszkolna (1932), Istota przedszkola (Yōchien-Hoikuho Shintei, 1934) oraz Pomyst na wychowanie dzieci (Sodate no Kokoro, 1936). W pracach tych autor przedstawił także propozycję ogólnokrajowego programu nauczania w przedszkolach i ośrodkach opieki dziennej ${ }^{15}$.

Warto w tym miejscu przytoczyć kilka elementów koncepcji Sozo Kurahashi. W pracy pt. Edukacja przedszkolna przedstawił on jej trzy zasadnicze cele:

${ }^{13}$ E. H. Ishigaki, The Historical Stream of Early Childhood Pedagogic Concepts in Japan, "Early Child Development and Care" 1991, nr 75, s. 123.

${ }^{14}$ N. Kamigaichi, Pedagogy in Japan..., s. 1169.

${ }^{15}$ M. Takeuchi, Children's Play in Japan, [w:] Roopnarine J. L., Johnson J. E., Hooper F. H. (red.), Children's Play in Diverse Cultures, SUNY Press, New York 1994, s. 57-58. 
- Nabywanie podstaw edukacji. Edukacja przedszkolna ma charakter fundamentalny w stosunku do całej edukacji. Pielęgnuje wartości ludzkie oraz potencjał samodzielności, które stanowią podstawę dalszego rozwoju.

- Rozwijanie kondycji fizycznej $i$ zdrowia. W celu rozwijania kondycji fizycznej i zdrowia nauczyciele powinni dawać dzieciom możliwość prowadzenia zabaw ruchowych (przykładem jest zabawa na świeżym powietrzu). Zajęcia takie motywują je do samodzielnego dbania o zdrowie.

- Rozwijanie dobrych cech charakteru. „Dobry charakter” w języku japońskim oznacza łagodność, współczucie oraz zażyłość z innymi. Jest również wysoko ceniony w społeczeństwie jako podstawowa i istotna cecha ludzka. Powinno się ją zatem rozwijać we wczesnym dzieciństwie poprzez rozważną i delikatną opiekę ze strony dorosłych.

Dalej Kurahashi zaproponował osiem metod edukacji przedszkolnej, które powinny doprowadzić do osiagnięcia wskazanych wcześniej celów. Były to:

1. Edukacja ukierunkowana na życie codzienne. Organizowana w celu wspierania rozwoju umysłu i ciała dzieci, programy edukacyjne powinny uwzględniać wszelkie aspekty ich codziennego życia. To znaczy, że ważne jest poszanowanie ich spontaniczności, niezaburzanie naturalnego nurtu ich życia oraz zapewnienie im warunków takich, aby miały silną motywację do życia.

2. Poszanowanie dla zabawy. To przez zabawę dzieci pokazują istotę swej natury. Zabawa daje im siłę do dalszego rozwoju i dlatego musi odgrywać kluczową rolę w rozwoju małych dzieci.

3. Zachęcanie do tworzenia relacji społecznych. Edukacja przedszkolna nie może zawierać wyłącznie wzajemnej relacji typu nauczyciel-dziecko. Ważne jest również, by dzieci miały możliwość doświadczania i tworzenia wzajemnych związków z rówieśnikami w celu ustalenia relacji społecznych.

4. Przygotowanie wtaściwego środowiska. Najlepszym środowiskiem przedszkolnym jest takie, w którym dzieci czują się swobodnie, zachowują się zgodnie ze swoją wolą, otrzymują dużo bodźców z otoczenia i dzięki temu realizują samospełnienie w swoim życiu codziennym. Ten element koncepcji Kurahashi - kładący nacisk na to, co otacza dziecko - został później zastosowany w ogólnokrajowych wytycznych, jako koncepcja edukacji poprzez środowisko.

5. Interweniowanie na czas. W celu kształtowania dzieci w poszanowaniu biegu ich życia, ważne jest, aby nauczyciele szukali właściwych możliwości interweniowania i wspierania ich.

6. Wspieranie motywacji do osiagania wyników i samozadowolenia. Nauczyciel powinien wyrażać uznanie dla dzieci, gdy poświęcają się swoim zajęciom oraz kontynuują je do momentu osiagnięcia wewnętrznego zadowolenia ze swoich działań. Daje im to poczucie samozadowolenia oraz pozwala budować dalszą motywację do osiągania celów.

7. Bezpośrednia zachęta. Nauczyciel pełni rolę osoby zachęcającej dzieci do podejmowania różnorodnych aktywności. Jest on jednym z elementów śro- 
dowiska społecznego. Metoda zachęcania polega przede wszystkim na zapraszaniu dzieci do uczestnictwa w życiu. Są one inspirowane przykładem oraz prowadzą swoje życie swobodnie, niezależnie i aktywnie.

8. Serdeczne interakcje $z$ dziećmi (Kokoro-mochi). Kokoro-mochi (pojęcie wprowadzone przez Kurahashi) oznacza współczucie lub empatię wobec uczuć oraz przeżyć innych ludzi. Gdy dzieci uczestniczą w życiu w pełni, powinny być serdeczne i kokoro-mochi. Nauczyciele winni przejawiać wrażliwość na kokoro-mochi każdego dziecka, wyrażać aprobatę dla tych uczuć i uznawać je za pozytywne przejawy funkcjonowania, a nie tylko wzmacniać intelektualne zainteresowania dzieci. Taka postawa pedagogów wzmaga poszanowanie dla indywidualności każdego wychowanka ${ }^{16}$.

Sozo Kurahashi jest też twórcą kategorii teoretycznej „samospełnienia”. W książce pt. Istota przedszkola autor ten stwierdza, że dzieci posiadają wrodzony potencjał samospełnienia oraz rozwijaja go poprzez swobodne i spontaniczne zabawy. Nauczyciele mogą wspierać tego rodzaju aktywności dzieci poprzez odpowiednią organizację otoczenia i tworzenie warunków pozamaterialnych, które gwarantuja podopiecznym poczucie swobody.

Koncepcja Sozo Kurahashi stanowi podstawę rozwoju japońskiej pedagogiki przedszkolnej i nadal wywiera ogromny wpływ na jej dzisiejszy kształt zarówno na poziomie teorii, jak i praktyki. Jego założenia zostały powszechnie zaakceptowane przez nauczycieli przedszkolnych i badaczy na początku XX wieku. Ustawa o przedszkolach z 1926 roku zapoczątkowała pełniejsze zaadoptowanie do praktyki pedagogicznej koncepcji Kurahashi ${ }^{17}$.

Tę intensywną fazę rozwoju edukacji przedszkolnej w Japonii przerywa zaangażowanie tego kraju w II wojnę światową. Następuje upolitycznienie oraz swoisty regres pedagogiki japońskiej, w tym również edukacji małego dziecka. Większość przedszkoli koncentruje się w swej praktyce edukacyjnej na nauczaniu dzieci patriotycznych piosenek i propagowaniu zwycięstw japońskiej $\operatorname{armii}^{18}$.

\section{Rozwój edukacji i opieki nad małym dzieckiem po II wojnie światowej}

W latach 1945-1952 miała miejsce w Japonii okupacja sił sprzymierzonych (zakończona podpisaniem traktatu pokojowego w San Francisco w 1952 roku). Ważną rolę w kreowaniu nowego systemu edukacyjnego odegrała Pierwsza

${ }^{16}$ N. Kamigaichi, Pedagogy in Japan..., s. 1170-1171.

${ }^{17}$ M. Takeuchi, Children's Play in Japan....., s. 58.

${ }^{18}$ Y. Oda, M. Mori, Current Challenges of Kindergarten (Yōchien) Education in Japan: Toward Balancing Children's Autonomy and Teachers' Intention, "Childhood Education", 2006, dok. elektr.: http://findarticles.com/p/articles.mi_qa3614/is_200601/ai_n17174790/ 
Amerykańska Misja Edukacyjna ${ }^{19}$. Eksperci amerykańscy zaproponowali nową formułę celów kształcenia uwzględniającą liberalizm i indywidualizm, zasadniczą rewizję programów nauczania (z usunięciem treści nacjonalistycznych i militarystycznych), decentralizację administracji oświatowej, ustanowienie publicznie wybieralnych lokalnych władz oświatowych, zmianę struktury systemu szkolnego z przedwojennego „wielościeżkowego” na ,jednościeżkowy", doskonalenie metod nauczania, radykalne zreformowanie kształcenia nauczycieli oraz unowocześnienie edukacji w zakresie języka japońskiego połączone z wprowadzeniem Roma-ji czyli liter rzymskich.

Po ogłoszeniu nowej, demokratycznej Konstytucji Japonii (1946), unieważniającej obowiązujące wcześniej Cesarskie Reskrypty oraz po wydaniu najważniejszych regulacji prawnych dotyczących edukacji zaistniały rzeczywiste warunki do zreformowania powojennego szkolnictwa japońskiego. Utworzony, na podstawie przyjętego ładu prawnego, jednolity system szkolny składał się z sześcioletniej szkoły podstawowej, trzyletniej niższej szkoły średniej, trzyletniej wyższej szkoły średniej, czteroletnich studiów uniwersyteckich lub dwu-, trzyletniego kolegium. Powojenna edukacja japońska stała się formalnie dostępna dla wszystkich dzieci i młodzieży bez względu na płeć, pochodzenie społeczne czy posiadany status ekonomiczny ${ }^{20}$.

Przedszkola japońskie zostały po II wojnie światowej włączone do systemu szkolnego. W 1948 roku uchwalono nowe wytyczne dotyczące opieki i edukacji małych dzieci o nazwie Hoiku Yoryo. Koncepcja Kurahashi stała się ich teoretyczną podstawą. Dokument powstał pod nadzorem Helen Heffernan, ekspertki amerykańskiej specjalizującej się w edukacji przedszkolnej. Następnie Hoiku Yoryo poddawane były kolejnym zmianom. Pierwsza ich rewizja (Ogólnokrajowe Standardy Programu Nauczania dla Przedszkoli) z 1956 roku wprowadziła sześć zakresów treści nauczania. Były to: zdrowie, kompetencje społeczne, przyroda, język, muzyka i rytmika oraz rysunek. W 1966 roku - w ramach drugiej rewizji - Ministerstwo Zdrowia i Opieki Społecznej opracowało wytyczne dla ośrodków opieki dziennej ${ }^{21}$.

Radykalna zmiana w sposobie myślenia o edukacji wczesnodziecięcej nastapiła w latach sześćdziesiątych i siedemdziesiątych XX wieku. Charakterystyczną tendencją tego okresu było postrzeganie edukacji jako „machiny” napędzającej wzrost ekonomiczny i rozwój przemysłowy Japonii. Teoria i praktyka edukacyjna zdominowane zostały przez dążenie do opracowywania i realizacji „strategii oświecania siły roboczej, która byłaby świadoma priorytetu wzrostu ekonomicznego". W konsekwencji różnych działań Ministerstwa

${ }^{19}$ Misja 27 ekspertów amerykańskich, pod kierownictwem dr G. D. S. Stoddarda, przybyła do Japonii w marcu 1946 roku.

${ }^{20}$ M. Cylkowska-Nowak, Społeczne funkcje szkolnictwa $w$ Japonii $i$ Stanach Zjednoczonych...., s. 71.

${ }^{21}$ Y. Oda, M. Mori, Current Challenges of Kindergarten... 
Edukacji wzrosła liczba instytucji kształcenia zawodowego, a w programach szkół podstawowych i średnich zaczęto coraz więcej wagi przywiązywać do nauczania nauk ścisłych i przedmiotów zawodowych ${ }^{22}$. Głównym celem instytucji przedszkolnych było zatem przygotowanie dzieci do jak najpełniejszego uczestnictwa w edukacji szkolnej na kolejnych poziomach japońskiego systemu szkolnego.

Lata sześćdziesiąte i siedemdziesiąte nazywane były w Japonii ,złotym wiekiem edukacji”. Wówczas to nastąpił ogromny ilościowy przyrost uczącej się i studiującej młodzieży. Społeczeństwo wywierało ogromną presję na młode pokolenie. Nauczaniu i wychowaniu towarzyszyła ścisła dyscyplina szkolna, hierarchizacja środowiska edukacyjnego oraz „egzaminacyjne piekło”. Zjawiska te ujawniały się także na poziomie edukacji przedszkolnej. Placówki edukacji wczesnodziecięcej zaczęły koncentrować się głównie na rozwoju intelektualnym dzieci, pomijając pozostałe sfery ich funkcjonowania. Mali Japończycy traktowani byli jak przyszli technokraci lub potencjalni eksperci, którzy mają wnieść znaczący wkład w potęgowanie wzrostu gospodarczego. W tak rozumianej edukacji wczesnodziecięcej nie było zatem miejsca na pełne upodmiotowienie dzieci. Na początku lat osiemdziesiątych pojawiło się wiele głosów krytycznie oceniających oświatę, w tym również działalność przedszkoli ${ }^{23}$.

W 1989 roku nastapiła kolejna rewizja wytycznych dla przedszkoli. Zatwierdzono wówczas edukację skoncentrowaną na dziecku jako podstawę edukacji przedszkolnej. Ponownie zadeklarowano edukacje poprzez środowisko, jak również konieczność osiagania trzech celów sformułowanych przez Sozo Kurahashi: edukację bliską nurtowi codziennego życia w warunkach odpowiednich dla małych dzieci, wszechstronną edukację poprzez zabawę oraz opiekę dostosowaną do cech każdego dziecka. Ważnym elementem poczynań nauczycieli i opiekunów miało być respektowanie autonomii i indywidualności podopiecznych. Treści edukacyjne zostały zawężone do pięciu dziedzin: zdrowia, relacji międzyludzkich, środowiska, języka i ekspresji ${ }^{24}$. Jednak w praktyce założone cele nie były w pełni osiaggane. Wiązało się to z oporem wielu nauczycieli edukacji wczesnodziecięcej przed pełnym upodmiotowieniem wychowanków. W latach dziewięćdziesiątych zapoczątkowano ogólnokrajową dyskusję wokół problemu respektowania autonomii i indywidualności dziecka. W 1997 roku Ministerstwo Edukacji powołało grupę roboczą, której zadaniem było opracowanie kierunków rozwoju przyszłej edukacji wczesnodziecięcej jako

${ }^{22}$ Wskazania ministerialne dotyczące tej kwestii zawarte zostały w takich dokumentach, jak na przykład Japan's Growth and Education (1962) czy Evolution of Education and Economic Development (1964) (por. M. Aso, I. Amano, Education and Japan's Modernization, Tokyo 1983, s. 81).

${ }^{23}$ N. Kamigaichi, Pedagogy in Japan..., s. 1171-1172.

${ }^{24}$ National Curriculum Standards for Kindergartens, dok. elektr.: http://www.mext.go.jp/ english/news/2001/04/010401.htm 
elementu szerszej zmiany społecznej zachodzącej w Japonii na przełomie XX i XXI wieku. W grudniu 1998 roku opublikowano kolejną rewizję standardów edukacji przedszkolnej ${ }^{25}$.

\section{Organizacyjne aspekty opieki nad małym dzieckiem w Japonii}

Tradycja japońska nakazuje sprawowanie opieki nad małym dzieckiem matce. Dlatego większość japońskich niemowląt jest wychowywanych w domu. Wraz z wiekiem odsetek dzieci przebywających w ciągu dnia w ośrodkach opieki dziennej oraz innych instytucjach wzrasta, ale nie przekracza jednej czwartej populacji w wieku 0-3 lat (tabela 1).

Tabela 1. Rozkład procentowy populacji dzieci japońskich (0-3 lat) w różnych formach opieki

\begin{tabular}{|c|c|c|c|}
\hline Wiek & Domy rodzinne & Ośrodki opieki dziennej & Inne instytucje opiekuńcze \\
\hline 0 & $92 \%$ & $4 \%$ & $3 \%$ \\
\hline 1 & $81 \%$ & $17 \%$ & $2 \%$ \\
\hline 2 & $74 \%$ & $22 \%$ & $4 \%$ \\
\hline
\end{tabular}

Źródło: Ministry of Welfare and Labor, 2003, podaję za: M. Hosbi-Watanabe, Infant and Toddler Care in Japan, [w:] . Early Childhood Education. An International Encyclopedia, t. 4, red. R. S. New. M. Cochran, Praeger, Westport-London 2007, s. 1183.

Jednym z powodów, dla którego matki japońskie porzucają pracę zawodową i poświęcają się wychowaniu dzieci jest rozpowszechniane w tym kraju przekonanie nazywane „legendą trzylatka”. W Japonii uważa się, że w celu zapewnienia prawidłowego rozwoju osobowości dziecka matka musi pozostawać w bezpośredniej relacji z nim i całkowicie odpowiadać za jego wychowanie do momentu osiągnięcia przezeń trzeciego roku życia ${ }^{26}$. Dlatego wiele matek osobiście opiekowało się (a także opiekuje się obecnie) własnymi dziećmi i nie wysyłało ich przed ukończeniem 3 roku życia do jakiejkolwiek formy instytucjonalnej opieki. Taka postawa Japonek zaczęła ulegać zmianie w latach osiemdziesiątych XX wieku. Wówczas to raptownie wzrosła liczba kobiet kontynuujących zatrudnienie po urodzeniu dziecka ${ }^{27}$. Grupa ta zaczęła preferować ośrodki opieki dziennej i rezygnować z pozostawiania dzieci pod opieką

${ }^{25}$ Y. Oda, M. Mori, Current Challenges of Kindergarten...

${ }^{26} \mathrm{H}$. Kojima, Child-rearing Concepts as a Belief-value system of the Society and the Individual, [w:] Stevenson H., (red.), Child Development and Education in Japan, Freeman, New York 1986, s. 40-44.

${ }^{27}$ B. Chung, Labor Market demand for Working Mothers and the Evolution of the Day Care System in Japan, "Sociology of the Family" 1988, Autumn, nr 2 (18). 
babć lub opiekunek ${ }^{28}$. W ciagu ostatnich piętnastu lat, liczba miejsc w ośrodkach opieki dziennej dla niemowląt wzrosła 1,8 razy (71000 dzieci) oraz 1,6 razy w przypadku małych dzieci w wieku od 1 do 2 roku życia (500000 dzieci). W niektórych miastach japońskich niemowlęta stanowią obecnie $10 \%$, a jednoi dwulatki aż 58\% dzieci na listach oczekujących na przyjęcie do ośrodków publicznych. Samorządy lokalne próbują reagować na wzrost zapotrzebowania na miejsca w ośrodkach opieki dziennej dla dzieci poniżej 3 roku życia. Największa liczba innych instytucji opieki nad dziećmi (opieka rodziny, sąsiedzka oraz świetlice opieki dziennej) znajduje się w dużych miastach, gdzie dostępność ośrodków opieki dziennej jest daleka od satysfakcjonującejej.

Historycznie, pierwszy ośrodek opieki dziennej w Japonii powstał pod koniec XIX wieku w rejonach wiejskich. Do tego rodzaju placówek przyjmowano dzieci z rodzin rolniczych na czas pracy ich matek w polu. Ponadto, w niektórych wiejskich szkołach podstawowych tworzono również świetlice opieki dziennej dla młodszych braci i sióstr uczniów. W przeciwnym razie dzieci te musiałyby opiekować się swoim rodzeństwem podczas zajęć szkolnych. Te wczesne rozwiązania polegały tylko na zapewnieniu sal i opiekunów (najczęściej bez formalnych kwalifikacji). Nie odbywała się tam żadna zaplanowana działalność edukacyjna.

Następnie na początku XX wieku, w części Tokio zamieszkanej przez ludność pochodzenia wiejskiego, otwarty został ośrodek opieki dziennej dla rodzin z klasy niższej. Kadrę tego ośrodka stanowili nauczyciele wykształceni we wspomnianym wcześniej Tokijskim Kolegium Nauczycielskim dla Kobiet. W tej placówce zajmowano się zarówno opieka, jak i kształceniem dzieci.

Pierwsze ośrodki opieki dziennej miały status prywatny i finansowane były przez darczyńców oraz działaczy społecznych. Nieco później powstawać zaczęły tego rodzaju instytucje publiczne. Początkowo celem obu rodzajów placówek było niesienie pomocy matkom i dzieciom z niższych klas społecznych. Po II wojnie światowej nastąiła zmiana w tym zakresie. Opieka nad małym dzieckiem stała się przedmiotem zainteresowania zarówno polityki edukacyjnej państwa, jak i polityki w zakresie opieki społecznej. Od 1948 roku państwowe ośrodki opieki dziennej podlegały Ministerstwu Opieki Społecznej. Wprowadzone centralnie wytyczne ministerialne zmieniły zakres ich działania - objęcie opieką i edukacją także dzieci powyżej 3 roku życia. Wytyczne nie były jednak akceptowane przez ośrodki prywatne oraz świetlice opieki dziennej. Placówki tego rodzaju kontynuowały pomoc dla pracujących matek i ich dzieci w wieku poniżej 3 lat. To spowodowało zróżnicowanie jakości opieki, jaką oferowały poszczególne instytucje. Niektóre prowadzone były w oparciu o zasady eduka-

${ }^{28}$ S. Vogel, Professional Housewife: The Career of Urban Middle-Class Japanese Women, „Japan Interpreter” 1978, nr 12, s. 16-43.

${ }^{29}$ M. Hosbi-Watanabe, Infant and Toddler Care in Japan..., s. 1183. 
cyjne, podczas gdy inne podejmowały jedynie działania opiekuńcze. Dopiero w 1972 roku powstał pierwszy państwowy ośrodek opieki nad niemowlętami. Instytucje prywatne mają nadal prawo wyboru zasad funkcjonowania. Niektóre $\mathrm{z}$ nich poddają się akredytacji (spełniając tym samym w pełni wytyczne ministerialne), podczas gdy inne działają bez akredytacji ${ }^{30}$.

Obecnie ośrodki opieki dziennej w Japonii podlegają formalnie Ministerstwu Zdrowia i Opieki Społecznej (Koseisho) oraz działają w oparciu o Ustawe o opiece społecznej nad dziećmi. Placówki tego rodzaju przyjmują dzieci w wieku od 2 miesiąca do 6 roku życia, których rodzice nie mogą sprawować opieki nad nimi z powodu wykonywania pracy lub choroby. W 2005 roku działało w Japonii 23000 ośrodków opieki dziennej, w których przebywało 2000000 dzieci. Blisko $30 \%$ tych dzieci było w wieku poniżej 2 roku życia. Do ośrodków tego rodzaju należą: publiczne (państwowe) ośrodki opieki dziennej (w 2003 roku stanowiły one 56\% ośrodków) prowadzone przez samorządy lokalne, akredytowane ośrodki prywatne (funkcjonujące w oparciu o te same zasady, co ośrodki publiczne) oraz nieakredytowane ośrodki prywatne. W przypadku publicznych i akredytowanych ośrodków opieki dziennej minimalne standardy materialne i kadrowe określane są przez Ministerstwo Zdrowia i Opieki Społecznej. Zgodnie z tymi wytycznymi na każde dziecko, które opanowało chodzenie powinna przypadać powierzchnia $1,65 \mathrm{~m}^{2}$, a w przypadku dzieci raczkujących $-3,3 \mathrm{~m}^{2}$. Czas pracy ośrodka to co najmniej dwanaście godzin dziennie. Wskaźnik liczby dzieci przypadających na jednego nauczyciela powinien wynosić odpowiednio: w grupie niemowląt -3, w grupie 1-2-latków 6. Poza nauczycielami i dyrektorem $\mathrm{w}$ ośrodku zatrudnić należy również pielęgniarkę, dietetyka i kucharzy.

Ośrodki nieakredytowane zwolnione są z utrzymywania standardów. Konsekwentnie, nie otrzymują rządowych dotacji. Niektóre z ośrodków dostosowują się do potrzeb matek, które w akredytowanych ośrodkach nie są uwzględniane. Na przykład istnieją ,hotele dla niemowląt”, których matki pracują bardzo długo lub w nocy.

Wytyczne, które określają ogólne kierunki rozwoju, zasady i cele oraz role nauczycieli, opiekunów i stosowane przez nich metody dla dzieci w każdej grupie wiekowej hoikuen wyznacza Ministerstwo Zdrowia i Opieki Społecznej. W przypadku dzieci w wieku do trzech lat wskazania te obejmują cztery zakresy, charakteryzujące zasady sprawowania opieki wobec następujących grup wiekowych: do 6 miesiąca życia, od 6 do 15 miesiąca, od 16 do 23 miesiąca i od 24 do 35 miesiąca życia. Działania opiekuńcze dotyczą zdrowia, czystości fizycznej, żywienia, rytmu życia i bezpieczeństwa. Jeśli chodzi o kształcenie, zgodnie z wytycznymi Ministerstwa Edukacji, przyjmuje się pięć dziedzin kształcenia: zdrowie, relacje międzyludzkie, zainteresowanie otaczającym śro-

${ }^{30}$ E. Lassergard, Japan ..., s. 324-325. 
dowiskiem, język i ekspresję, przy czym edukacją obejmowane są raczej dzieci powyżej trzeciego roku życia.

Zgodnie $\mathrm{z}$ wytycznymi w przypadku opieki nad dziećmi w wieku poniżej 15 miesiąca życia ośrodki opieki dziennej odpowiedzialne są za promocję zdrowia, czystość fizyczną i żywienie. W placówkach tego rodzaju konieczne jest też ustalenie rytmu życia, stworzenie bezpiecznych warunków funkcjonowania dziecka oraz rozwijanie więzi emocjonalnej pomiędzy nauczycielem a każdym dzieckiem znajdującym się pod jego opieką. Uważa się, że wzbudzenie i podtrzymywanie takiej więzi emocjonalnej z opiekunem jest szczególnie istotne dla psychicznego bezpieczeństwa dziecka. Dlatego też dochodzi do częstej interakcji pomiędzy dorosłym a niemowlęciem, która polega na kontakcie fizycznym, takim jak dotykanie, noszenie i zabawa w bliskości fizycznej. W Japonii uważa się, że zabawa z dorosłymi stymuluje ciekawość, która z kolei wzmaga rozwój poznawczy.

Jedzenie dla niemowląt przygotowuje się w zróżnicowany sposób, w zależności od wieku dziecka wyrażonego w miesiącach. Nawet w okresie odstawiania od piersi posiłek ma na celu nie tylko karmienie, ale również powinien stanowić okazję do zabawy i odczuwania zmysłowych doświadczeń estetycznych. Kucharze przygotowują posiłki o różnych smakach i kolorach, tak aby dzieci z każdej grupy wiekowej mogły czerpać radość z ich spożywania. Ponieważ dla dobrego funkcjonowania podopiecznych istotnym elementem jest sen i bezpieczeństwo emocjonalne, nauczyciel towarzyszy dziecku do momentu zaśnięcia. Pieluchy są zmieniane często. Przyzwyczaja to dziecko do bycia czystym oraz pozwala wyrobić wrażliwość na brak czystości. Ponadto, istotnym zadaniem wyznaczanym w ramach działalności japońskich ośrodków opieki dziennej jest obcowanie z naturą. Dlatego wychodzenie z dziećmi na zewnątrz praktykuje się często Jest ono także postrzegane jako nieodzowny element promowania zdrowia. Pora roku i warunki pogodowe nie powinny ograniczać kontaktu małych dzieci z naturalnym środowiskiem.

Kolejnym zadaniem instytucji opieki nad małym dzieckiem jest usamodzielnianie. Jest ono zapoczątkowywane pomiędzy 15 a 23 miesiącem życia. W Japonii powszechny jest pogląd, że dzieci mogą stawać się samodzielne wyłącznie po osiągnięciu bezpieczeństwa emocjonalnego oraz dzięki przywiązaniu do nauczycieli. $Z$ tego punktu widzenia istotnym jest, aby rozwinąć i nie zniszczyć tak ważnej więzi pomiędzy dzieckiem a dorosłymi. Pierwsza faza usamodzielniania polega na uczeniu dziecka samodzielnego jedzenia, posługiwania się łyżką, kubkiem oraz korzystania z toalety. Ponadto, podczas zabawy i zajęć na świeżym powietrzu zachęca się dzieci do ruchu np. wchodzenia i schodzenia ze schodów, pokonywania naturalnych przeszkód w ogrodzie.

Od dwulatków wymaga się większej samodzielności. Mianowicie powinny one z pomocą nauczyciela zdejmować ubranie, samodzielnie myć ręce, jeść czy chodzić do toalety. Pozytywnie postrzegane i nagradzane jest nawiązywanie 
relacji z innymi dziećmi. Rozmowy $\mathrm{z}$ nauczycielami, oglądanie obrazków w książkach i przedstawień teatralnych postrzega się jako sytuacje umożliwiające zabawę poprzez mówienie, recytacje. Podczas aktywności na świeżym powietrzu do rozwijania indywidualnych działań twórczych oraz samodzielnego poznawania przyrody wykorzystywane są takie materiały jak woda, piasek, błoto, kwiaty, liście i nasiona ${ }^{31}$.

W Japonii rozwijana jest także dzienna opieka rodzinna. W systemie tym uprawniony opiekun, często nazywany „dzienną mamą” opiekuje się nie więcej niż trójką dzieci poniżej 3 roku życia we własnym domu. Ten rodzaj działalności opiekuńczej jest organizowany i kontrolowany przez samorządy lokalne. Samorządy zapewniają ,dziennym mamom” środki finansowe oraz kierują do nich rodziców zainteresowanych umieszczeniem własnego dziecka pod opieką „dziennej mamy”. Od momentu wprowadzenia tego systemu w Kyoto, w latach pięćdziesiątych ubiegłego wieku, ośrodki takie stanowią rodzaj „poczekalni” do ośrodków opieki dziennej. Ich liczba została ograniczona (1400 opiekunów w 120 okręgach samorządowych w roku 1999) i skoncentrowana w obszarach miejskich. Niemniej w ostatnich latach system ten podlegał zmianom z powodu różnorodności potrzeb dzieci i ich matek. Taki model opieki wybierają rodzice, którzy chcą, aby ich dzieci wychowywane były w warunkach rodzinnych, a nie w środowisku zbiorowym. Zadaniem samorządów lokalnych jest zadbanie o jakość opieki sprawowanej przez „dzienne mamy” - zarówno w kontekście kwalifikacji kobiet podejmujących tego rodzaju działalność, jak i warunków, w których przebywają dzieci ${ }^{32}$.

Jak wcześniej wspomniano, obok omówionych około 23000 hoikuen czyli ośrodków opieki dziennej dla dzieci w Japonii funkcjonują także przedszkola (yōchien). Uczęszczają do nich dzieci w wieku od 3 do 6 lat. Ich głównym celem jest przygotowanie podopiecznych do startu szkolnego. W działalności przedszkoli w mniejszym stopniu uwzględnia się pełnienie funkcji opiekuńczej. Jest to związane z faktem, iż do yōchien posyłane są dzieci niepracujących matek.

Tabela 2. Rozkład liczbowy przedszkoli w Japonii w latach 1955-2005 według typu placówki

\begin{tabular}{|c|c|c|c|c|c|}
\hline Rok & $\begin{array}{c}\text { Liczba } \\
\text { ogółem }\end{array}$ & Państwowe & $\begin{array}{c}\text { Publiczne } \\
\text { lokalne }\end{array}$ & $\begin{array}{c}\text { Prywatne (w tym } \\
\text { korporacje szkolne) }\end{array}$ & $\begin{array}{c}\text { Odsetek } \\
\text { prywatnych }\end{array}$ \\
\hline 1 & 2 & 3 & 4 & 5 & 6 \\
\hline $\mathbf{1 9 5 5}$ & 5426 & 32 & 1893 & $3501(532)$ & 64,5 \\
\hline $\mathbf{1 9 6 0}$ & 7207 & 35 & 2573 & $4599(786)$ & 63,8 \\
\hline $\mathbf{1 9 6 5}$ & 8551 & 35 & 3134 & $5382(1027)$ & 62,9 \\
\hline $\mathbf{1 9 7 0}$ & 10796 & 45 & 3908 & $6843(2003)$ & 63,4 \\
\hline
\end{tabular}

\footnotetext{
${ }^{31}$ M. Hosbi-Watanabe, Infant and Toddler Care in Japan...., s. 1184-1186.

${ }^{32}$ Tamże, s. 1186.
} 
Tabela 2 (cd.)

\begin{tabular}{|c|c|c|c|c|c|}
\hline 1 & 2 & 3 & 4 & 5 & 6 \\
\hline $\mathbf{1 9 7 5}$ & 13106 & 47 & 5263 & $7796(3111)$ & 59,5 \\
\hline $\mathbf{1 9 8 0}$ & 14893 & 48 & 6064 & $8781(4818)$ & 59,0 \\
\hline $\mathbf{1 9 8 5}$ & 15220 & 48 & 6269 & $8903(6356)$ & 58,5 \\
\hline $\mathbf{1 9 9 0}$ & 15076 & 48 & 6243 & $8785(6770)$ & 58,3 \\
\hline $\mathbf{1 9 9 5}$ & 14856 & 49 & 6168 & $8639(6986)$ & 58,2 \\
\hline $\mathbf{2 0 0 0}$ & 14451 & 49 & 5923 & $8479(7119)$ & 58,7 \\
\hline $\mathbf{2 0 0 5}$ & 13949 & 49 & 5546 & $8354(7253)$ & 59,9 \\
\hline
\end{tabular}

Źródło: MEXT, Educational Statistics, 2006, dok. elektr. http://www.,ext.go.jp/english. statist/index.htm

Niewielka jest w Japonii liczba przedszkoli państwowych (finansowanych z środków centralnych). Ich liczebność jest stała od 1995 roku (49). Pozostałe publiczne yōchien finansowane i prowadzone są przez lokalne władze oświatowe. Najwięcej przedszkoli ma status prywatny (tabela 2). Występują wśród nich instytucje świeckie i wyznaniowe, pojedyncze placówki oraz korporacje sieciowe oraz tzw. gakuen, będące elementem pełnej prywatnej struktury szkolnej obejmującej wszystkie typy szkół po uniwersytet włącznie ${ }^{33}$.

Obowiązujący w edukacji przedszkolnej program nauczania ma swoje podstawy prawne. Japońskie przedszkole stanowi jedną z instytucji szkolnych podlegających Ustawie o edukacji szkolnej. Artykuł 77 tego dokumentu stanowi, że ,,celem przedszkola jest opieka i edukacja małych dzieci poprzez zapewnienie odpowiedniego środowiska oraz zachęcanie ich do rozwijania umysłów i ciał". Szczegółowe założenia programu nauczania znajdują się w Artykule 76 przepisów wykonawczych do Ustawy o edukacji szkolnej, nazywanych Ogólnokrajowymi Standardami Programu Nauczania dla Przedszkoli. Wytyczne te stanowią obecnie podstawę programu nauczania dla dzieci od 3 do 6 roku życia w przedszkolach i ośrodkach opieki dziennej ${ }^{34}$.

Ogólnokrajowe Standardy Programu Nauczania dla Przedszkoli wyznaczają ramy czasowe działalności przedszkoli. Powinny być one otwarte nie więcej niż trzydzieści dziewięć tygodni w roku, przez cztery godziny dziennie. Ostatnio dopuszcza się jednak pewną elastyczność w stosowaniu tego przepisu. Coraz częściej przedszkola przyjmują dzieci na zajęcia trwające dłużej niż zostało to określone prawnie.

${ }^{33}$ EFA, 2000, Assessment country Reports: Japan, dok. elektr.: http://www.unesco.org/ education/wef/countryreports.japan.rapport_1html; MEXT, Educational Statistics, 2006, dok. elektr. http://www.,ext.go.jp/english.statist/index.htm

${ }^{34}$ T. Kawabe, Curriculum in Japanese Early Childhood Education, [w] New R. S., Cochran M. (red), Early Childhood Education. An International Encyclopedia, t. 4, Praeger, Westport London 2007, s. 1173. 
Wytyczne wskazują, że przedszkola powinny brać pod uwage przyszłe kształcenie małych Japończyków, tak aby cele edukacji były realizowane w ramach wszystkich aspektów doświadczenia dzieci w przedszkolu, od rozpoczęcia do zakończenia oraz w każdym momencie codziennego życia wychowanków. Nauczyciele winni także wspierać rozwój dzieci głównie poprzez zabawę, dostosowując funkcjonowanie przedszkola do faz rozwojowych wychowanków. Cele edukacji wczesnodziecięcej nie mogą być zatem osiagane poprzez kierowanie dziećmi przez nauczyciela.

Małe dzieci mogą rozwijać się i poszerzać swój wewnętrzny świat, gdy czują się akceptowane i kochane przez dorosłych. Jeśli kształcenie przedszkolne zbudowane jest na poczuciu zaufania do nauczycieli dzieci wykazują zainteresowanie różnymi rzeczami, z własnej woli angażują się w zabawę, w której wykazują pozytywny stosunek do innych ludzi i zdarzeń. Nauczyciele muszą zapewnić realizację programu nauczania, który gwarantuje osiagnięcie tych aspektów rozwoju wychowanków.

Program nauczania w każdym przedszkolu opracowywany jest stosownie do wieku dzieci. Choć wszystkie dzieci z tej samej grupy wiekowej podlegają jednemu programowi nauczania to uwzględnia się również różnice indywidualne. Nauczyciele zobowiązani są przygotowywać różne ścieżki edukacyjne odpowiednio do fazy rozwojowej każdego dziecka. Zwykle przygotowywane są dwa programy nauczania. Pierwszy jest krótkoterminowy i obejmujący plany I zajęcia dzienne i tygodniowe. Drugi ma charakter długoterminowy i zawiera miesięczne, semestralne i roczne plany oraz harmonogramy zajęć. Podstawą przygotowania obu programów jest ta sama sekwencja czynności: zrozumienie rzeczywistości dzieci poprzez obserwację; ustalenie celów edukacji; zorganizowanie wspierającego środowiska; modyfikacja celów lub zmiana środowiska na podstawie obserwacji i oceny. Zarówno w długo- jak i krótkoterminowej perspektywie najważniejsze dla nauczycieli jest pełne zrozumienie dzieci i ich potrzeb.

Jakie są najlepsze warunki w przedszkolu dla rozwoju małych dzieci? Jednym z nich jest ten, który pozwala dziecku na zgodne z jego wolą poznawanie otaczającego świata przy pomocy metody prób i błędów. W toku takich zabaw nabywane są różnorodne umiejętności. Często są one ukryte, ich wpływ trudno jest stwierdzić natychmiast. Ujawniają się w późniejszym życiu. Jednakże z powodu ostatnich trendów społecznych i edukacyjnych żąda się od dzieci natychmiastowych efektów edukacji. Dlatego coraz większa liczba przedszkoli realizuje program nauczania zorientowany na osiaganie celów. Duża liczba możliwych interpretacji Ogólnokrajowych Standardów Programu Nauczania dla Przedszkoli pozwala na rozwijanie przez przedszkola różnych programów nauczania. Taki stan rzeczy może w naturalny sposób wzbudzać konkurencję pomiędzy placówkami ${ }^{35}$.

\footnotetext{
${ }^{35}$ T. Kawabe, Curriculum in Japanese Early Childhood Education, s. 1175.
} 
W japońskich przedszkolach i ośrodkach opieki dziennej główną częścią programu nauczania są doświadczenia dzieci zdobyte podczas zabawy. Zasadniczym jej walorem jest osiaganie przez wychowanków samodzielności. Japońska koncepcja programu nauczania przedszkolnego nie zakłada, aby dzieci nabywały wiedzę i umiejętności poprzez systematyczne, szkolne uczenie się. Jest to raczej rodzaj programu nauczania, w którym nauczyciel podejmuje jakiś aspekt doświadczenia dziecka i skupia się na nim, daje wychowankowi związane z nim wskazówki oraz umieszcza te sytuacje w różnorodnych aktywnościach zabawowych. Takie podejście do strukturyzowania treści kształcenia nazywane jest programem nauczania opierającym się na doświadczeniu. Jeśli dziecko interesuje się np. ptakami, nauczyciel podejmuje próbę pogłębienia tego zainteresowania. Planuje zajęcia o ptakach, zadania związane z rysowaniem, nazywaniem oraz przygotowaniem obrazkowej książki na temat ich życia oraz sposobu ich chronienia. Dziecko powinno być zafascynowane zajęciami. Doświadczenia tego rodzaju rozwijają w nim zdolności obserwacyjne, badawcze, umiejętność wyrażania uczuć oraz poszanowanie dla życia innych stworzeń. Taką koncepcję programu nauczania uznano w Japonii za pożądaną w przypadku edukacji wczesnodziecięcej, gdyż w oparciu o jej realizację zapoczątkowany zostaje rozwój trwający całe życie ${ }^{36}$.

Wczesne dzieciństwo utożsamiane jest w Japonii z okresem życia, w którym dzieci wzbogacają swoje uczucia, kształtują jednoznaczne postawy w odniesieniu do różnych zjawisk otaczającego je świata oraz stają się świadome pojęć i wydarzeń poprzez konkretne i bezpośrednie doświadczenia. Edukacja w przedszkolach i ośrodkach opieki dziennej jest organizowana w celu osiagnięcia tych aspektów rozwoju, a zabawa stanowi jego centralny proces. Jednak zabawa nie oznacza „dawania wolnej ręki”. Pomimo poszanowania autonomii dzieci I ich woli nauczyciele podejmują decyzję o tym, jakie doświadczenia są potrzebne danej jednostce w określonym momencie, rozważają jakie zajęcia i warunki środowiskowe będą dla nich optymalne, a następnie planują i budują rzeczywiste środowisko sprzyjające rozwojowi.

\section{Kierunki przyszłych zmian}

Edukacja i opieka małego dziecka w Japonii znajduje się obecnie w okresie przejściowym. Zaprojektowano cztery znaczące kierunki jej rozwoju. Pierwsza z nich to konieczność zaspokojenia zmieniających się potrzeb. W sytuacji, gdy wzrasta liczba pracujących matek, różnorodność metod pracy wymaga zróżnicowanych form opieki dziennej, np. przyjmowania dzieci na noc; zorganizowania sal opieki dla dzieci, które są chore; usytuowania ośrodków opieki dziennej

${ }^{36}$ R. Irie, Play in Japanese Early Childhood Education, [w] New R. S., Cochran M. (red), Early Childhood Education. An International Encyclopedia, t. 4, Praeger, Westport - London 2007, s. 1178 . 
i przedszkoli (dla wygody rodziców dojeżdżających do pracy) w pobliżu stacji metra itp.

Drugi kierunek wiąże się ze sposobem, w jaki lokalna administracja japońska może lepiej wspierać matki pracujące w pełnym wymiarze czasu pracy. Miejski styl życia oraz zanik modelu rodziny wielopokoleniowej spowodowały ujawnienie się poczucia izolacji u młodych matek. Niektóre badania wskazują, że wiele matek postrzega wychowywanie dzieci jako ciężką pracę. Gwałtowny spadek wskaźnika urodzeń już w latach dziewięćdziesiątych wywołał ogromne poruszenie rządu i społeczeństwa. Między innymi z tego powodu Ministerstwo Zdrowia i Opieki Społecznej oraz samorządy lokalne wprowadziły różne programy wspierające wychowywanie dzieci. Niestety niewystarczające środki finansowe oraz brak długoterminowych planów działania przyczyniły się do tego, że programy te nie są w pełni i skutecznie realizowane. Ośrodki opieki dziennej oraz przedszkola próbując sprostać coraz bardziej zróżnicowanym potrzebom matek (i tym niepracującym, i tym zaangażowanym zawodowo), podejmuja nowe, niepraktykowane dotąd w Japonii formy pracy. W wielu placówkach zorganizowano tymczasową formę opieki dziennej, zajęcia grupowe o charakterze edukacyjnym i wspierającym dla matek czy też doraźne konsultacje (bezpośrednie, telefoniczne, mailowe). Jednak często zadania te realizowane są bez zatrudniania dodatkowej, wyspecjalizowanej kadry lub przeszkolenia pracowników już zatrudnionych w ośrodkach ${ }^{37}$.

Trzecia tendencja, która pojawiła się w niektórych dużych miastach japońskich to prywatyzacja publicznych ośrodków opieki dziennej. Ten kierunek rozwojowy budzi najwięcej kontrowersji bowiem często oznacza to zwolnienie dotychczas funkcjonujących placówek z przestrzegania minimalnych standardów. Niektóre z prywatyzowanych ośrodków prowadzone są przez przedsiębiorców kierujących się zasadami rynkowymi. Celem naczelnym - obok generowania zysku - jest dostosowywanie się do potrzeb klientów, którymi w tej relacji są raczej matki, a nie dzieci.

Czwarty, proponowany kierunek zmian to przekształcanie obecnych przedszkoli i innych instytucji w nowe organizacje nazywane „rozszerzonymi instytucjami opieki i kształcenia" (comprehensive facilities of care and education). Maja one powstawać przy współpracy Ministerstwa Edukacji oraz Ministerstwa Zdrowia i Opieki Społecznej. System ten stosuje różne modele opieki i kształcenia $\mathrm{w}$ jednej instytucji: przedszkole, ośrodek opieki dziennej, tymczasową opiekę dzienną, świetlicę dla dzieci i rodziców itd. Chociaż rozwiązanie takie, ze względu na swoją elastyczność, wydaje się być idealnym miejscem opieki, to zainicjowany został bez wystarczającego przygotowania. Na przykład nauczyciele przedszkolni bez przeszkolenia opiekują się aktualnie niemowlętami i odwrotnie opiekunowie małych dzieci pracują z przedszkolakami ${ }^{38}$.

${ }^{37}$ J. Arioka, Fewer Babies: A Private Matter?, "Japan Quarterly” 1991, nr 1 (38), s. 50-56.

${ }^{38}$ M. Hosbi-Watanabe, Mode de garde et éducation des enfants de moins de trios ans au Japon, [w:] G. Brougère, S. Rayna (red.), Traditions et innovations dans l'éducation préscolaire, INRP, Paris 2000, s. 92-94. 
Rzeczywistość społeczna stawia zatem organizatorów i realizatorów opieki nad małymi dziećmi w Japonii przed szeregiem dylematów i problemów do rozważenia. Wielu z nich zaczyna poszukiwać także adekwatnych podstaw teoretycznych, które ułatwiłyby podejmowanie optymalnych dla opieki nad małym dzieckiem decyzji.

MirosŁawa CyLKOWSKA-NOWAK

\section{Early education in Japan - curricula and organization transformation}

The aim of this paper is the analysis and the description of early childhood education and care in Japan. The one country comparative study explores curricula and organization aspects of different education and care solutions. "Education" and "care" are combined in the phrase to underline that services for young children have to combine care, development and learning opportunities.

The paper consists five parts, which describe: genesis of early childhood education and care in Japan; early adaptation and elaboration of curricula; development of new education and care solutions after second world war; organizational aspects of early childhood education and care in Japan; and development prognosis. 